\title{
The Impact of Organizational Factors in Ethical Decision Making of Albanian Accountants
}

\section{Loreta Bebi}

\author{
Aleksandër Xhuvani University/ Finance Department, Elbasan, Albania
}

Teuta Xhindi

European University of Tirana/Informatics, Statistics and Mathematics Department, Tirana, Albania

\begin{abstract}
The role of professional accountant is increasing in developed countries, part of which is also Albania. According to recent studies, accountants' ethics behaviour is not appropriate even though it is one of the most essential attributes that an accountant should possess in order to fulfil its mission. Various scholars admitted that during the process of decision making, accountants are influenced by individual and organizational factors. This paper aims to analyse the impact of organizational factors in ethical decision making of Albanian accountants. The article is based on primary data using a questionnaire and generating 230 respondent accountants that work in Albania. After data analysing we conclude that the code of ethics (the companies ethical climate and the type of industry where the accountant works) influences the decision making process. Meanwhile, the size of company is not an influential factor.
\end{abstract}

Keywords: albania, ethical decision making, accountant, organizational factors, ethical climate,code of ethics, type of industry

\section{Introduction}

The modern financial science complexity requires not only deepen theoretical framework but also a developed methodology to conclude in a realistic, rational and scientific context. The basis upon which relies the business unit reputation is related to the employees' individual behaviour, including different positions. It has a substantial and direct impact on the market value, on customers, investors, employees or consumers. Accounting, as a profession, is important for country development, since it contributes to the economic development, financial stability and efficient operation of capital markets and public sector. Accountants encourage and support the growth and development of business sector as well as strategic financial direction. Their aim is to ensure the interests of shareholders and the public that invests capital. Therefore, they represent successful people. According to studies, a successful accountant - regardless of the various businesses, human and technical abilities - must necessarily support the ethical standards (Taicu, 2007; Amat, Blake \& Dowds, 1991). Accountants are often obliged to choose in different situations.(Shaub, 2005). To improve ethical behaviour, it is vital to better understand the involved components in the decision-making process and ethics impact on them. According to Jackling, Cooper, Leung, \& Dellaportas (2007) education in terms of accounting ethics helps in amending the ethical collapse of the profession. For example, this study on Albania as one of the developing countries seeks to determine the effect of organizational factors on ethical decision-making for accountants.

\section{The theorical background of ethical decision making process and organizational factors.}

The decision making process is difficult and complicated due to several factors and circumstances that should be taken into account. This process becomes even more difficult when it comes to accountants who are engaged in responsible decisions regarding the units they manage. The performance of the unit depends on these decisions. Each of us can easily imagine that personal ethical values and decision making processes that an individual uses in his daily life, are influenced by a number of internal and external factors. The following factors are combined to form an individual opinion for a given situation, ranging from important personal issues to those dealing simply with what an individual is required to do every day at his work place (Caldwell, Bischoff, \& Karri, 2002; Polkinghorne, 2005). Individual ethics derives from the individual's 
experience and can be influenced by a number of other important factors (Burns, 2004; Weston, 2001). The most acclaimed models of ethical decision making (Jones, 1991; Rest, 1986; Trevino, 1986) are based on descriptive theories and assume that the process of ethical decision making is influenced by a number of individual and organizational factors as well as the characteristics of ethical issues (Nill et al., 2004). The theoretical framework developed by Rest (1986) is considered as one of the most important articles related to the individual's decision making process within the organization. In the initial model of ethical decision-making, Rest (1986) defines four stages through which emerges the process. Later this model was improved to support the fact that psychological factors affect any moral action. (Rest et al., 1986, 1999). He proposes a process, which goes through four phases, as follows: ethical knowledge (the ability to make the difference if we deal with an ethical situation or not) ethical judgment (the ability to decide which is the right procedure) ethical goal (the ability to give priority to ethical alternatives versus other alternatives) and ethical behaviour (the ability to undertake ethical behaviour). Rest (1986) argues that each stage or phase is conceptually different and that success in the first phase does not necessarily impose success at the next stage. Trevino (1986) offered an interactive model of ethical decision making, which was mostly built based on the Recognition Theory of Moral Development by Kohlberg (1969). In her model she adopts three parts from Rest's model of the ethical decision making. In this complex model she describes the ethical decision making process in three stages. This process starts with ethical issues recognition, continues with recognition process and concludes with concrete actions. Individual factors, as well as organizational ones, are included in this process. According to Trevino (1986), ethical decision-making is the product of individual and organizational factors interaction related to the individualizing thought about the ethics of dilemmas. The involvement of these factors, in the decision making structures of ethical theory, is considered as one of the main developments in the area of business ethics research. This paper aims to identify the relationship between the ethical decision making process and the organizational factors in these models starting from the Rest model(1986) - that we will in this study to achieve goals. According to the literature, the individual decisionmaking process (in the case of accountants) depends to a considerable extent on the work environment. There are some organizational factors such as climate, ethics, the code of ethics, the size of company or the industry where the company operates, which are certified by the previous empirical researches to have a positive impact on the individual who takes an ethical decision. Organizational factors are defined as the characteristics of the background of a decision, which affect the ethical decision making process and its results (Ross \& Robertson, 2003). Trevino (1986) concluded that some organizational factors often create obstacles to the individual's ethical decision making. However research on ethics has been very limited regarding accounting field in general and organizational factors in particular. Therefore, the findings regarding these factors, cast some empirical evidence in the accounting ethics literature in general and ethical decision making in particular. The code of ethics is considered as one of the most widely used tools by organizations aiming to direct the elections of their employees (Pater \& Anita, 2003; Schwartz, 2002). It treats some common ethical issues that organization members face in their place of work. The code of ethics enhances the reputation of the organization and the brand image (Singh, Carasco, Svensson, Wood \& Callaghan, 2005). Stevens (1994, p.64) defines the code of ethics as a written document through which corporations hope to model the behaviour of their employees and produce changes by making clear statements about the desired behaviour. In his summary Craft (2013) noted that during 2004 to 2011 the number of researches about analysing the impact of the code of ethics and the process of ethical decision making, has dropped significantly. According to the McKinney study, (2010), professionals working in organizations that have implemented a written code of ethics tend to address controversial ethical issues as less acceptable than those working in organizations that do not have an implemented ethical code. As noted, the number of studies related to the relationship between the first three phases of ethical decision making and the existence of a code of ethics, has been declining. In conclusion we can say that on behalf of these studies, it is noted that different results have been reached, but it should also be noted that most of them support the idea that the existence of the code of ethics is positively related to ethical decision making. Ethical climate is one of the most important organizational factors, which appears to have a significant impact on the ethical decisions of employees at their place of work. Victor \& Cullen (1988) defines ethical climate as "the primary perception of practices and typical procedures of the organization, which have ethical content". They argue that the ethical climate in the workplace is the primary source of information for employees on the right or ethical actions in the organization. Martin \& Cullen (2006) add that the ethical climate can be understood as the entirely procedures, policies and common practices, both formal and informal, within the organization. Using theories of moral philosophy and moral psychology, Victor \& Cullen (1987) designed the Ethical Climate Questionnaire in order to identify the ethical climate of the organization or the group. The Ethical Climate Questionnaire (ECQ) analyses the perceptions of individuals within the organization about how members of the organization act based on the ethical issues they face. ECQ specifies certain necessary events, practices and procedures in order to establish the criteria for ethical decision making. The reason for choosing these three 
dimensions is firstly related to the fact that these dimensions are known based previous empirical studies; therefore this paper suggests that these dimensions will be noticed in Albanian companies as well. Even though there have been a number of studies related to ethical climate, there is still little literature concerning factors linking these stages of the decision making process (Martin \& Cullen, 2006). According to the Craft's summary (2013), a sum of ten studies is conducted regarding this issue; two of them were specifically related to the stage of ethical knowledge, four of them related to ethical judgment and the others with ethical purpose. It should be stressed that the Forte research (2004), concluded that there is a statistically significant correlation between levels of management and the organization's ethical climate. The industry is thought to have an impact on individual ethical behaviour $(\mathrm{Oz}, 2001)$. People who work in a place where dangerous products are produced, for example narcotics, may be more sensitive to ethical issues, compared to people who work for companies that produce safe products like furniture. Business ethics literature continues to produce mixed and inconsistent results, in terms of impact of the organisation quantity in ethical decision making. According to recent research, there are significant correlations between factors.

\section{The purpose and the objectives}

The main purpose of this paper is to establish organizational factors that affect the ethical decision making process of Albanian accountants as they make the most important decisions within the company.

The aim of the paper is to determine the impact of organizational factors in the accountant's decision making process in Albania.

The research question discussed in this article is: What impact do organizational factors have in the ethical decision making process?

The hypothesis is:

\section{The organizational factors have a significant impact on ethical decision making process.}

The organizational factors include: the code of ethics, ethical climate, size/quantity and industry.

The following under-hypothesis has been raised for the main hypothesis:

The industry has a significant impact on ethical decision making. (1)

The size of the company has a significant impact on ethical decision making. (2)

The existence of the code of ethics in the company has a significant impact on ethical decision making. (3)

The ethical climate has a significant impact on ethical decision making. (4)

\section{Methodology}

This article generates a considerable added value for young researchers and accountants who practice their profession in our country, whether they are employed in Albanian companies or free acting professionals. Regarding the selection of companies whose accountants would be part of the study, it was reasonable to concentrate at the large Albanian companies as these companies represent the biggest taxpayers. According to Zikmund (2003), the primary data are exclusively collected for the research on which they are working. There are several methods for collecting primary data, but in this paper we have chosen the questionnaire as the main tool. Van der Stede et al., (2007) defines it as the most useful method for researches and studies conducted in the field of accounting. The questionnaire was constituted based on two main parts. The first part collected information on the company size, type of industry, the code of ethics and the ethical climate of the company. In order to measure and determine the type of ethical climate of each company where the accountants are working — the Ethical Climate Questionnaire built by Victor \& Cullen (1987) was used.

In the second part, through four different scenarios, the participants were asked to rate the hypothetical action of the individual who makes the decision through a likert scale. The first phase of decision making, i.e: the ethical recognition is directly measured by asking participants through a likert scale with five categories, to express their opinion about the statement if "the above situations comprise an ethical problem" (Singhapaki et al., 1996).

The ethics trial phase was measured by asking participants directly through the likert scale with five categories to express 
the extent to which they agree with the statement "(the decision maker) should not have done this" (May \& Pauli, 2002).

The ethical goal is measured in the same way by asking participants to express the extent to which they agree with the statement "If I had been the decision maker, I would have done the same thing/action" (Singhapakiet al., 1996). In this paper we chose the method of distributing the questionnaires via email, because of the significant distance of the unit locations. The distribution of questionnaires by mail, obviously like any other distribution has its advantages. 571 questionnaires were distributed to the Albanian companies and from those only 230 returned completed. The response rate in this study is $40.3 \%$. This is a very satisfactory result if we consider the fact that this form of distribution of questionnaires typically provides a low level of responses returned. Once the data were collected, they were coded and processed with SPSS 20.0 .

\section{The results}

We dealt with the following results after data collection.

The first under-hypothesis is related to the company where the individual (accountant) operates.

Ho: Company does not have a significant influence in the ethical decision making. (1) By carrying out the ANOVA test after the data was processed, Table (1) is obtained. Table (1) indicates that sig. $=0.001<=0.05$. This means that we disprove the null hypotheses based on (1) and accept the alternative one.

This means that the industry has a major influence on ethical decision making. This result is consistent with a previous series of studies where Ergenelei \&Arikan (2002); Krambia-Kapardis \&Zopiatis (2008); Shafer (2007), can me mentioned.

The second under-hypothesis is related to the impact of company size in the ethical decision making.

: The company size has not a significant impact on ethical decision making. (2)

By carrying out the ANOVA test, Table 2 was generated. In this table, based on sig. $=0.253>=0.05$ we can not disprove the null hypothesis (2). This means that the size of the company does not have a significant impact on ethical decision making. Despite different opinions about the impact of the size of the company in the process of ethical decision makingthis study reached to the conclusion that the company size does not have a significant impact on this process. Such a result is in line with other studies, such as Razzaque \& Hwee (2002); Roozen et al. (2001); Paolillo \& Vitella (2002), etc.

\section{The third under-hypothesis is related to the impact of the code of ethics.}

: The existence of a code of ethics in the company does not have a significant influence in ethical decision making. (3) After processing the data, performing the Independent Samples t-test we obtained the following table 3. In table 3, because sig. $=0.561>=0.05$, we meet the condition of equal variances of the two populations. Furthermore, as Sig. (2-tailed) $=0.003$ $<\alpha=0.05$, means that the null (3) hypothesis is disproved and the alternative one is accepted. This indicates that the code of ethics in a company has a significant impact on ethical decision making. The reached result is consistent with some previous studies, where Singh et al. (2005); Wotruba, Chonko \& Loe (2001) can be mentioned.

The fourth under-hypothesis is related to the ethical climate impact of ethical decision making.

: The ethical climate does not have a significant impact on ethical decision making. (4)

By carrying out the ANOVA test, we obtained the following Table 4. In this table, because sig. $=0.032<=0.05$, we disprove the null (4) hypothesis. Hence, we conclude that ethical climate has a major influence on ethical decision making. From the three types of ethical climate taken into consideration, the ethical decision making process is more strongly influenced by the "Law and the Professional Code". Thus, from the four organizational factors taken into consideration, it is noticed that three of them have a significant impact on the ethical decision making process of our accountants.

It is noted that the kind of company has a greater impact compared to the code of ethics and the ethical climate. Between the last two factors, the code of ethics is more important than the ethical climate. The result achieved regarding the size of the company is consistent with several other studies, where Paolillo \& Vitell (2002);. However it should be noted that there are different opinions about the impact of the size of company. We can mention Clarke (1996), who claims that the bigger is, the greater is the possibility that these companies benefit from the implementation of various helpful mechanisms, which can't be found in small companies to support ethical decisions that individuals of these companies make. Vitell \& Festervant 
(1987) claim that small companies forced to compete large companies are more likely to be engaged in unethical issues. According to Albanian accountants the size of company is not an influential factor when these individuals are forced to make decisions about ethical issues. The main reason for achieving such an outcome could be related to the fact that the study includes the most important companies of our country. The classification criteria in order to be classified in the group of large taxpayers in our country, is the annual turnover of these companies. This means that within the group of large taxpayers, there may also be companies with four or five employees in total. The industry where the company operates, represents the factor with the greatest impact on the ethical decision making process. $\mathrm{Oz}$ (2001) claims that the industry has a significant impact on the ethical behaviour of accountants. According to him, individuals who work in places where dangerous products are produced, for example drugs, are more sensitive to Ethical issues than individuals who work for companies that produce safe products, such as furniture. In our case "Trade" has the most significant influence on ethical decision making, compared to other types of industry. For this reason, this group of companies operating in this sector should be given more attention on ethics and its regulation.

The impact of the Ethics Code on the ethical decision making process for accountants is ranked based on this factor. The result achieved in this study is consistent with several other studies, where Pater \& Anita (2003); Adams, Tashchiang \& Shore (2001); Granitz (2003) and others can me mentioned. The fact that this factor has a significant impact proves that codes are recognized and respected by the employees of each company. In the Albanian companies the Codes of Ethics do not only represent the formal documents to comply with the law. There are some scholars who claim that a Code of Ethics on its own is not sufficient to significantly influence the ethical decision making process (Cooper \&Frak 1997; Verschoor 2002). Rottig \&Heischmidt (2007) have concluded that the Code of Ethics should be examined in a systematic and empirical way along with several other determinants of ethical decision making, such as ethical training.

According to the study, the Code of Ethics is not the only organizational factor which has an impact on ethical decision making. Another influential factor is also the ethical climate of the company. According to Victor \& Cullen (1988) the ethical climate is defined as the dominant perceptions of typical organizational practices and procedures which have ethical content.

According to them, a company's ethical climate is the main factor, which helps to inform workers about the lawful and ethical actions within the organization. Three types of ethical climates considered in this study have important impact on Albanian accountants during the ethical decision making process. Although it is a new notion and only recently known by Albanian companies, it can be stated that the ethical climate has taken its belonging position in term of importance.

Companies in our country, although slowly, have managed to implement the ethical climate, regardless of its type. This factor has been improving and an important role in this case has had the new spirit that the foreign investors have brought. The main reason for achieving these results regarding the organizational factors may relate to the fact that the Albanian companies operate in the free market.

According to Agareal \& Malloy (1999) the organizational factors do not define decision making process in state-owned companies because they have a relatively limited control of their employees. The fact that our companies operate in a competitive free market, fully supports the results obtained from this study about organizational factors. There are some previous studies, which prove that these factors have a significant impact on the stages of the process of ethical decision making of companies operating in a free market (Barnett et al., 1993; Granitz, 2003; Plugrath et al. 2007)

\section{Conclusion}

Organizational factors constitute a very important factor with a considerable impact on accountants as individuals during the process of decision making. According to the results, a special importance should be paid to these factors. Ethical behaviour and the right decision of accountants concerning any ethical dilemma which they face in their work place make possible the provision of accurate and reliable information. The leaders of an entity, by using this information have the possibility to make the right decisions regarding the future of the entity which they govern. Particular attention should be paid to the creation of an ethical climate in the work environment as well as the communication and application of the code of ethics by employees in general and accountants in particular.

\section{References}

[1] Amat, O, Blake,J, Dowds, J(1991), "The Ethics of Creative Accounting", Journal of Economic Literature 
Classification: M41.

[2] Burns, J. M. (2004). Foreward. In J. B. Ciulla (Ed.), Ethics, the heart of leadership (2nd ed.). Westport, CT: Praeger Publishers.

[3] Caldwell, Cam; Bischoff, Sheri J. \& Karri, Ranjan (2002). The four umpires: A paradigm for ethical leadership. Journal of Business Ethics 36 (1-2), 153 - 163.

[4] Craft, Jana L. (2013). A Review of the Empirical Ethical Decision-Making Literature: 2004-2011. Journal of Business Ethics 117 (2):221-259

[5] Forte, A. (2004). Business ethics: A study of the moral reasoning of selected business managers and the influence of organizational ethical climate. Journal of Business Ethics, 51(2), 167-173.

[6] Jackling, B., Cooper, B. J., Leung, P., \& Dellaportas, S. (2007). Professional accounting bodies' perceptions of ethical issues, and ethics education. Managerial Auditing Journal, 22(9), 928-944.

[7] Jones, T. M. (1991). Ethical decision making by individuals in organization: An issue contingent model. Academy of Management Review, 16(2), 366-395.

[8] May, D. R., \& Pauli, K. P. (2002). The role of moral intensity in ethical decision making: A review and investigation of moral recognition, evaluation, and intention. Business \& Society, 41(1), 84-117.

[9] Nill, A., Schibrowsky, J. A., \& Peltier, J. W. (2004). The Impact of competitive pressure on students' ethical decision-making in a global setting. Marketing Education Review, 14(1), 0-73.

[10] Oz, E. (2001). Organizational commitment and ethical behavior: An empirical study of information system professionals. Journal of Business Ethics, 34(2), 137-142.

[11] Pater, A., \& Anita, V. G. (2003). Stimulating ethical decision-making in a business context: Effects of ethical and professional codes. European Management Journal, 21(6), 762-772.

[12] Rest, J. R., Bebeau, M., \& Volker, J. (1986). Taking stock: can the theory of reasoned action explain unethical conduct. In J. R. Rest (Ed.),Moral development pp. 1-27. New York: Praeger Publishers.

[13] Ross, W. T., \& Robertson, D. C. (2003). A typology of situational factors: Impact on salesperson decision-making about ethical issues. Journal of Business Ethics, 46(3), 213-234

[14] Singh, J., Carasco, E., Svensson, G., Wood, G., \& Callaghan, M. (2005). A comparative study of the contents of corporate codes of ethics in Australia, Canada and Sweden. Journal of World Business, 40(1), 91-109.

[15] Singhapakdi, A., Vitell, S. J., \& Kraft, K. L. (1996). Moral intensity and ethical decision-making of marketing professionals. Journal of Business Research, 36(3), 245-255.

[16] Stevens, B. (1994). An analysis of corporate ethical code studies: "Where do we go from here?" Journal of Business Ethics, 13(1), 63-69.

[17] Taicu, M (2007) "Ethics in Management Accounting", Scientific Bulletin Economic Science. Vol. 9.Treviño, L. K. (1986). Ethical decision making in organizations: A person-situation interactionist model. Academy of Management Review, 11(3), 601-617.

[18] Van der Stede, Wim A., Young, S. Mark and Xiaoling Chen, Clara (2007) Doing management accounting survey research. in: Chapman, Christopher S., Hopwood, (eds.) Handbook of Management Accounting Research. Elsevier Science, pp. 445-478. ISBN 9780080445649.

[19] Victor, B., \& Cullen, J. B. (1987). A theory and measure of ethical climate in organizations. Research In Corporate Social Performance and Policy, 9, 51-71.

[20] Weston, A. (2001). A 21st century ethical toolbox. New York, NY: Oxford University Press.

[21] Zikmund, William G (2003). Business research methods (7th ed). Thomson/South-Western, Cincinnati

Tables

Table 1. Results of Anova Test About the Type of Company

\begin{tabular}{|l|l|l|l|l|l|}
\hline \multicolumn{2}{|l|}{ ANOVA } \\
\hline \multicolumn{2}{|l|}{ Ethical decision making } \\
\hline & $\begin{array}{l}\text { Sum of } \\
\text { Squares }\end{array}$ & df & $\begin{array}{l}\text { Mean } \\
\text { Square }\end{array}$ & F & Sig. \\
\hline $\begin{array}{l}\text { Between } \\
\text { Groups }\end{array}$ & 440.4 & 7 & 62.9 & 3.6 & .001 \\
\hline $\begin{array}{l}\text { Within } \\
\text { Groups }\end{array}$ & 3810 & 216 & 17.6 & & \\
\hline Total & 4250.5 & 223 & & & \\
\hline
\end{tabular}


Table 2. Results of the Anova Test About the Company's Size

\begin{tabular}{|c|c|c|c|c|c|}
\hline \multicolumn{6}{|l|}{ ANOVA } \\
\hline \multicolumn{6}{|c|}{ Lotucal detkos raking } \\
\hline & Suar ü Squant: & JI & Meen Squint & b & $\mathrm{Sij}_{\mathrm{i}}$. \\
\hline 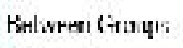 & 16. 3 & 4 & $21:$ & 11 & 281 \\
\hline Wirth.s. Groups & 4148.2 & 219 & 18.8 & & \\
\hline Total & 4250.5 & $2 \hat{2} 3$ & & & \\
\hline
\end{tabular}

Table 3. the Results of the Independent Samples Test About the Existence of the Code of Ethics

\begin{tabular}{|c|c|c|c|c|c|c|c|c|c|c|}
\hline \multicolumn{11}{|c|}{ Independent Samples Test } \\
\hline & & \multicolumn{2}{|c|}{$\begin{array}{l}\text { Levene's Test } \\
\text { for Equality } \\
\text { of Variances }\end{array}$} & \multicolumn{7}{|c|}{ t-test for Equality of Means } \\
\hline & & \multirow[t]{2}{*}{ F } & \multirow[t]{2}{*}{ Sig. } & \multirow[t]{2}{*}{$\mathrm{t}$} & \multirow[t]{2}{*}{ df } & \multirow{2}{*}{$\begin{array}{l}\text { Sig. } \\
\text { (2- } \\
\text { taile } \\
\text { d) }\end{array}$} & \multirow[t]{2}{*}{$\begin{array}{l}\text { Mean } \\
\text { Diffe } \\
\text { rence }\end{array}$} & \multirow{2}{*}{$\begin{array}{l}\text { Std. } \\
\text { Error } \\
\text { Differe } \\
\text { nce }\end{array}$} & \multicolumn{2}{|c|}{$\begin{array}{l}95 \% \text { Confidence } \\
\text { Interval of the } \\
\text { Difference }\end{array}$} \\
\hline & & & & & & & & & Lower & Upper \\
\hline \multirow[t]{2}{*}{$\begin{array}{l}\text { Ethical } \\
\text { decision }\end{array}$} & $\begin{array}{l}\text { Equal } \\
\text { variances } \\
\text { assumed }\end{array}$ & .339 & .561 & 3.021 & 222 & .003 & 1.788 & .592 & .622 & 2.954 \\
\hline & $\begin{array}{l}\text { Equal } \\
\text { variances }\end{array}$ & & & 2.974 & $\begin{array}{l}166.3 \\
76\end{array}$ & .003 & 1.788 & .601 & .601 & 2.975 \\
\hline
\end{tabular}

Table 4. the Results of the Anova Test About the Ethical Climate

\begin{tabular}{|l|l|l|l|l|l|}
\hline ANOVA & $\begin{array}{l}\text { Mean } \\
\text { Ethical decision making } \\
\text { Squares }\end{array}$ & df & $\begin{array}{l}\text { Square } \\
\text { Sig. }\end{array}$ & F & Sig \\
\hline $\begin{array}{l}\text { Between } \\
\text { Groups }\end{array}$ & 138.4 & 2 & 69.209 & 3.510 & .032 \\
\hline $\begin{array}{l}\text { Within } \\
\text { Groups }\end{array}$ & 3864.7 & 196 & 19.718 & & \\
\hline Total & 4003.1 & 198 & & & \\
\hline
\end{tabular}

